УДК 378.147:78.07

DOI:

Ліна Котова, кандидат педагогічних наук, доцент кафедри інструментального виконавства та музичного мистецтва естради Мелітопольського державного педагогічного університету імені Богдана Хмельницького Тетяна Юник, кандидат педагогічних наук, доцент кафедри кіно-телемистецтва Київького національного університету культури і мистецттв

\title{
ПСИХОЛОГІЧНА ПІДГОТОВКА МАЙБУТНІХ УЧИТЕЛІВ МУЗИЧНОГО МИСТЕЦТВА ДО ПУБЛІЧНИХ ВИСТУПІВ
}

У статті розглянуто вплив індивідуальних особливостей виконавиів на результативність діяльності перед публікою. Вказано на залежність виступів від темпераменту, інтроверсії(екстраверсіі), належності до репресорів (приховувачів) та міри емоційного збудження. Запропоновано методи психологічної підготовки майбутніх вчителів музичного мистецтвв до прилюдної гри: встановлення початково-вихідної мотивачії, запам'ятовування оптимальних психофізіологічних станів виконавських апаратів, визначення провідних об'єктів уваги.

Ключові слова: майбутні вчителі музичного мистецтвва; публічні виступи; нервова система; методи; сиенічне хвилювання.

Jim. 9.

Lina Kotova, Ph.D.(Pedagogy), Associate Professor of the Instrumental Performances and Music Stage Art Department, Melitopol Bohdan Khmelnytskiy State Pedagogical University Tetyana Yunyk, Ph.D.(Pedagogy), Associate Professor of the Cinema and Film Art Department, Kyiv National University of Culture and Art

\section{PSYCHOLOGICAL PREPARATION OF THE FUTURE TEACHERS OF MUSICALART TO THE PUBLIC PERFORMANCE}

The influence of the individual peculiarities of the performers to the results of the actions in front of the public is looked around in the article. It is pointed to the independence of the performance from the power-weakness of the nervous system, temperament introversion (extraversion), belonging to the repressors (hidden) and the measures of the emotional excitation.

There are five types of the musician's reactions to the stress: tense cowardly, braking, aggressive, progressive. It is determined, that during the public performance the individuals have their own sensority and motor stamina. Sensor stamina is less determined by the balance of the nervous processes. Motor stamina, near the lower degree of the skill, corrects with the natural features of the nervous system enough strong. It is noticed in the article that the attention becomes worse during the performance, performers with the low types of temperament in comparison with the usual situations, but the ones with the strong types of temperament, it is opposite. In the researching it is announced that the meaning of the psychological options not absolute, their unusual dependence is explained by the differences of the conditions of the actions.

The methods of psychology preparation of the future teachers of musical art are suggested to the public show: the estate or correction of the elementary motivation (due to the change of the purpose, improving self-determination and the form of the reporting), the rememberance of the optima psychophysiological stations of the performance's apparatus, the determination of the objects attention.

In the conclusion need to say, that individual peculiarities of the future teachers of musical art is necessary to point not only in the angle of the formal-dynamic features, but from the side of the characteristic of the whole process of the musical art. It is shown the independence of the successful psychological preparation of the future specialists from the creation of pedagogical conditions, which create the search and correction of the power of motivation, domination of the stage's emotions, self-regulations of the psychophysiological station.

Keywords: the future teachers of musical art; public performances; nervous system; methods; the stage's excitement.

П остановка проблеми. Одним 3 важливих завдань педагогічної науки на сучасному етапі $є$ підготовка конкурентоспроможної особистості, яка здатна діяти в екстремальних ситуаціях. Процес психологічної підготовки фахівців до таких умов привертає увагу не одного покоління науковців. Дослідження охоплюють велике коло різних професій, пов’язаних з розумовими, фізичними та психічними навантаженнями. 3 цих позицій потребує вирішення обрана проблема і у майбутніх учителів музичного мистецтва, адже їх 


\section{ПСИХОЛОГІЧНА ПЦДОТОВКА МАЙБУТНІХ УЧИТЕЛІВ МУЗИЧНОГО МИСТЕЦТВА}

ДОПУБЛІЧНИХ ВИСТУПІВ

виконавська діяльність характеризується відчуттям емоційного та психологічного напруження i, навіть, стресу.

Аналіз основних досліджень і публікацій. Питанням психологічної підготовки до публічних виступів присвячені праці як українських так зарубіжних дослідників. Педагоги та науковці вказують на залежність результативності виконання музичної інформації від впевненості (невпевненості) у собі (Л. Бочкарьов, С. Гмиріна, К. Кондрашин, Д. Мергалієв); роботи когнітивних процесів (О. Віцинський); уваги (М. Давидов, Ю. Цагареллі); міри відповідальності (Л. Лабінцева, В. Петрушин); навичок саморегуляції (В. Бурназова, О. Лучиніна, О. Матвєєва). Під час безпосередньої гри на сцені Д. Юник рекомендує застосовувати чотири вектори завадостійкості з наданням пріоритету першому “як найбільш сприятливого для інтерпретаторської діяльності..., за якого уникається перцепція стресорів" [9, 310]. Науковець наголошує на застосуванні когнітивної чи емоційної емпатії, наявних варіантів імпровізації, зручного локусу контролю (зовнішнього чи внутрішнього) та уникнення "конфлікту установок” [9, 312]. Проте, серед різноманітного арсеналу методів роботи над музичними творами в період підготовки до виступів перед аудиторією, на наш погляд, обраній проблемі приділяється недостатня увага як в практиці навчання так і в наукових пошуках [4].

Мета статті - розкрити ефективні методи психологічної підготовки майбутніх учителів музичного мистецтва до публічних виступів.

Виклад основного матеріалу дослідження. Сценічне хвилювання у музичній педагогіці та психології розглядається як індивідуальна реакція виконавця на стресову ситуацію (Л. Бочкарьов, А. Готсдінер, В. Петрушин, Ю. Цагареллі, Д.Юник). У роботах аналізується вплив силислабкості нервової системи на інструменталістів через динамічну й статичну витривалість. Під останньою розуміється здібність довгочасно виконувати твори без заниження рівня інтенсивності та якості відтворення матеріалу. Тому виконавці зі слабкою нервовою системою надають перевагу мініатюрам [7, 19]. Значна залежність естрадного самопочугтя спостерігається від типутемпераментуінструменталістів, природна основа якого пов'язана з різними проявами нервової системи (силою, рівновагою, швидкістю). Під час виступів перед публікою, в більшості випадків, негативні властивості того чи іншого типу темпераменту дають про себе знати і, навіть, підсилюються. Проте, за допомогою систематичних тренувань небажані прояви темпераменту можна нівелювати, а потрібні покращити і зробити їх домінуючими [3, 184]. О. Лучиніна та $€$. Винокурова, спираючись на дослідження $€$. Мілеряна, описують п'ять типів реакції музикантів на стрес: напружений (відчугтя скутості, імпульсивність, звуженість кола уваги); боязливий (паніка, відчуття страху); гальмівний (уповільненість рухів, притупленість реакцій); агресивний (втрата контролю, вияв агресії); прогресивний (відчуття творчого підйому та оптимального емоційного стану) $[5,41]$.

В загально-психологічному аспекті ще В. Небиліциним було виявлено залежність якості діяльності в емоціогенних умовах від силислабкості нервової системи особистості. Проте така залежність не завжди є однозначною, адже то один, то другий $з$ двох протилежних параметрів кожної властивості нервової системи може відігравати як позитивну так і негативну роль. Зниження працездатності (під час довгочасної одноманітної діяльності) у суб'єктів слабкого типу нервової системи, раніше ніж у сильного, - було виявлено В. Рождєствєнською [6]. При чому перші можуть більше реагувати на довгочасне повторення монотонних подразників, ніж останні. Крім того, індивіди зі “слабкою” нервовою системою стрес монотонії проявляли у випадках дефіцитузовнішньої директивної інформації. Автор зазначила, що слабкій нервовій системі, на відміну від сильної, недостатньо власних внутрішніх енергетичних ресурсів для підтримки функціонального тонуса в період дії стресфакторів.

При вивченні індивідуальної стресової реакції у психолого-педагогічних дослідженнях виявляємо кореляцію результативності дій від рівня тривожності та експресивності особистості (А. Бєлкін, Л. Гіссен, Л. Китаєв-Смик, Л. Котлярова), іïтемпераменту(А. Готсдінер,Р. Лазарус,В.Петрушин), невротичності (Ж. Піаже, П. Фресс), належності до інтроверсії чи екстраверсії (I. Григор'єв, Г. Магомедова, О. Масляєв), розподілу на репресорів та приховувачів (С. Бюрхфілд) та мірою емоційного збудження (Я. Рейковський. Д. Юник) Кожна людина має свій поріг чутливості до стресу - той рівень напруги, при якому ефективність діяльності підвищується (настає евстрес), а також критичний поріг виснаження, коли ефективність діяльності знижується (настає дистрес) [8, 7]. Тут простежується існування порогової величини емоційного збудження майбутніх учителів мистецтва, де амплітуда першої їі “частини" позитивно впливає на успішність публічної діяльності, а другої - негативно. Утворенню “оптимальної” міри збудження сприяють стійкі 


\section{ПСИХОЛОГІЧНА ПІДГОТОВКАМАЙБУТНІХ УЧИТЕЛІВ МУЗИЧНОГО МИСТЕЦТВА ДО ПУБЛІЧНИХ ВИСТУПІВ}

переживання позитивних відчуттів в процесі підготовки до виступів. Л. Аболін вказує на провідну роль (в структурі механізму емоційної регуляції) спонукальних емоцій, які спонукають до участі в регуляції цілісних актів діяльності й окремих виконавських рухів. Такі відчуття впливають на регулюючі функції емоцій “впевненості - сумніву” та емоцій “оцінки результатів" $[1,30]$.

Слід зазначити, що на рівень емоційного збудження безпосередньо впливає сила мотивації. Надмірна мотивація до діяльності виконавців в емоціогенних умовах, в мить допущення ними помилки, досить часто викликає високий ступінь емоційного збудження, тобто перевищує його порогову величину. Хоча така тривога не завжди порушує злагодженість відтворення засвоєного матеріалу, оскільки ії протиставленням може бути сила початково-вихідної мотивації. Саме вона $€$ домінуючою при негативному впливі зовнішніх стресорів на майбутніх вчителів музичного мистецтва.

Отже, аналізуючи вищезазначене, в експериментальній частині дослідження варто враховувати можливість позитивного чи негативного впливу на результативність публічних виступів рівня збудження майбутніх учителів мистецтва та особливостей їх нервової системи.

Перш за все, у процесі психологічної підготовки до публічних виступів створювалися педагогічні умови, які активізували прагнення якісно засвоїти музичну інформацію. За допомогою анкетування, насамперед, виявлялася функціонально-спонукальна сторона початкововихідної мотивації. До основної частини анкети було включено чотири закритих дихотомічних запитання, а саме:

1) чи отримуєте Ви задоволення від успішного виконання музичних творів перед шкільною аудиторією або під час заліків та іспитів?;

2) чи пов'язуєте Ви рівень виконавської майстерності 3 основного інструменту 3 майбутнім матеріальним добробутом?;

3) чи усвідомлюєте Ви соціальну потребу власного високого рівня майстерності гри на музичному інструменті?;

4) чи $є$ духовною потребою для Вас гра на музичному інструменті?

Результати анкетування надали змогу констатувати: більшість майбутніх учителів музичного мистецтва експериментальної групи (79,2\%) отримували задоволення від успішного виконання музичних творів перед публікою та відчували духовну потребу у грі на інструменті; лише $58,3 \%$ опитуваних пов'язували рівень своєї виконавської майстерності 3 майбутнім добробутом. Слід зазначити, що майбутні фахівці, які готувалися до Всеукраїнського конкурсу на всі запитання анкети дали відповідь “Так”. У зв'язку з тим, що музичний репертуар було вже сформовано, сила початково-вихідної мотивації простежувалася завдяки аналізу мети, бажаної результативності майбутнього підсумкового виступу та працелюбства кожного. За необхідністю здійснювалася іï корекція в бік сильної, завдяки зміні мети, підвищенню самовимогливості та значимості форми звітності 3 урахуванням визначальних потреб кожного студента (матеріальних, духовних, соціальних), що спонукали його до діяльності. У майбутніх конкурсантів простежувалася надмірно сильна початково-вихідна мотивація. Вона була відкоректована до оптимальної завдяки зменшенню значимості майбутньої форми звітності і розгляду конкурсу не як "пікового" в становленні виконавської особистості. Таким способом відчуття сумніву та невпевненості, котрі викликали страх за майбутню результативність виступу і викликали почуття пригнічення, були переведені в стенічні емоції. Це дало змогу поліпшити їх працездатність й зберегти вимогливість до якості засвоєння музичного матеріалу.

Важливим наступним кроком психологічної підготовки до публічних виступів було встановлення та запам'ятовування майбутніми фахівцями оптимальних психофізіологічних станів виконавського апарату, котрі забезпечують успішність виконання кожного епізоду музичних творів. Запам'ятовування проводилося 3 метою довільного відтворення таких станів у будь-яких умовах. Для цього майбутнім учителям музичного мистецтва давалися вказівки: декілька раз програти перший фрагмент музичного твору i 3 кожним повторенням змінювати психофізіологічну напругу від мінімальної до максимальної; визначити та запам'ятати міру психофізіологічної напруги, при якій епізод виконується найкраще; встановити оптимум психофізіологічної напруги для наступного фрагменту; об'єднати опановані епізоди 3 обов'язковим відтворенням оптимальної міри психофізіологічної напруги виконавського апарату і т.д.

Варто зазначити, що майбутнім учителям музичного мистецтва 3 рухливою нервовою системою властива висока працездатність в напружених умовах, а інертній - характерна знижена активність, яка, досить часто призводить до надмірної тривожності. При низькому рівні 
майстерності гри виконавці зі слабкою нервовою системою, завдяки наявності високої чутливості, у звичних умовах виступу виявляють себе більш стійкими від виконавців сильного типу нервової системи. Проте, в умовах підвищеної відповідальності у перших спостерігається надмірна тривожність, що призводить до невротизму та розгубленості, а в других, навпаки - до оптимального емоційного стану.

Необхідно, також, зауважити, що під час прилюдного виступу індивідам властивий вияв сенсорної та моторної стійкості. Вони корелятивно пов' язані між собою, але по різному залежать від сили-слабкості нервової системи відносно впливу стрес-факторів та рівня майстерності виконання інформації. Сенсорна стійкість досить мало визначається балансом нервових процесів, проте, все ж таки, у виконавців 3 низькою майстерністю гри простежується його дія. Так, при відтворенні музичного матеріалу перед публікою у виконавців слабкого типу темпераменту розподіл уваги погіршується в порівнянні зі звичними ситуаціями, а в сильного типу, навпаки, - покращується. Моторна стійкість при низькому рівні майстерності виконання корелює з природженими властивостями нервової системи досить сильно.

То ж наступним кроком психологічної підготовки майбутніх учителів музичного мистецтва до публічних виступів було визначення ними провідних об'єктів уваги при виконанні кожного епізоду творів. Для цього їм рекомендувалося: декілька разів програти перший фрагмент і встановити й запам'ятати об'єкти мимовільного спрямовування уваги при найрезультативнішій грі; таким методом опрацювати наступний епізод музичного твору; “об'єднати“ ці фрагменти, “відтворюючи” при програванні “програму” довільного спрямовування уваги на запам'ятовані об'єкти; досягти цілісного програвання всієї програми зі збереженням провідних об'єктів уваги при виконанні кожного фрагменту музичних творів. За повторним програванням коло уваги могло змінюватися, але в ньому залишалися ті ж самі об'єкти. Саме вони становилися провідними.

3 метою "набуття" концертної форми створювалися педагогічні умови поступового збільшення в учасників експериментального дослідження емоціогенного навантаження. Спочатку виконання програми здійснювалося “перед мікрофоном", тобто з записом як в присутності викладачів так і без них. Наступне коло слухачів складали друзі. В роботі 3 майбутніми конкурсантами враховувалися зовнішні фактори, що впливають на психічні стани в умовах музичного змагання, представлені Л. Бочкарьовим.

- новизна ситуації, що часто впливає на якість виступів у першому турі;

- жеребкування;

- робота фото-та кінооператорів під час прослуховувань;

- масштаб, місце проведення та рівень організації конкурсу (значення має не тільки міжнародний авторитет конкурсу, а й суб' єктивна оцінка його значущості учасником) $[2,26]$.

3 досягненням бажаної результативності гри та впевненості в готовності до концертних виступів твори програвалися перед малими аудиторіями. Частота зміни слухацьких аудиторій поступово збільшувалася. Кожен “виступ" ретельно аналізувався, відповідно до успішності виконання зазначених настанов.

Висновки і перспективи подальших досліджень. Обробка даних результатів експериментального дослідження засвідчила ефективність запропонованих методів психологічної підготовки майбутніх учителів музичного мистецтва (позитивна динаміка склала 18 \%), що дозволяє зробити наступні висновки:

1) диференціація факторів впливу на утворення індивідуального рівня збудження, які визначають структуру особистісно-змістовних утворень відображає перспективу поліпшення творчого процесу публічних виступів;

2) значення психофізіологічних параметрів властивостей нервової системи не абсолютне, їх неоднозначна залежність обумовлена різноманітністю внутрішніх й зовнішніх умов діяльності;

3) індивідуальні властивості майбутніх вчителів музичного мистецтва необхідно розглядати не тільки в ракурсі формально-динамічних особливостей, але й 3 боку змістовних характеристик цілісного процесу музичновиконавської діяльності;

4) успішність психологічної підготовки майбутніх фахівців залежить від створення педагогічних умов, які сприяють пошуку та корекції сили мотивації; домінуванню стенічних емоцій; саморегуляції психофізіологічного стану виконавського апарату.

Перспективність дослідження обраної проблеми вбачаємо у з'ясуванні умов застосування майбутніми фахівцями загального психофізіологічного стану безпосередньо у прилюдному виступі, що має забезпечувати швидкість активації відповідних слідів у довгочасній пам'яті. 


\section{ПСИХОЛОГЧНА ПДГОТОВКАМАЙБУТНІХ УЧИТЕЛІВ МУЗИЧНОГО МИСТЕЦТВА ДОПУБЛІЧНИХ ВИСТУПІВ}

\begin{tabular}{lc}
\hline \hline \multicolumn{1}{c}{ ЛІТЕРАТУРА } & М. \\
1. Аболин Л. М. Эмоциональная устойчивость & Ext \\
в напряженной деятельности, её психологические & [ \\
механизмы и пути повышения: автореф. дисс. на \\
соискание учён. степени доктора психол. наук : \\
спец. 19.00.01 “Общая психология”. Москва, 1990. \\
43 с.
\end{tabular}

2. Бочкарёв Л. Л. Психологические аспекты формирования готовности музыкантовисполнителей к публичному выступлению: дисс. ... канд. психол. наук : 19.00.01. Москва, 1974. $176 \mathrm{c}$.

3. Готсдинер А. Л. Подготовка учащихся к концертным выступлениям. Методические записки по вопросам музыкального образования. Москва, 1991-1992. С. 182-192.

4. Котова Л .М. Вплив емоціогенних умов на надійність виконання музичних творів майбугніми вчителями мистецтва. Молодь $i$ ринок: щзомісячний науково-педагогічний журнал. Дрогобич, 2016. № 5 (136). С. 93 - 98.

5. Лучинина О.А., Винокурова Е.С. Практическая психология для музыкантов. Астрахань, 2008. 144 с.

6. Рождественская В.И. Индивидуальные различия работоспособности. Москва, 1980. 152 с.

7. Цагарелли Ю. А. Психология музыкальноисполнительской деятельности: дисс. ... доктора психол. наук : 19.00.03. Казань, 1989. 425 с.

8. Щербатых Ю. В. Экзаменационный стресс (диагностика, течение и коррекция). Воронеж. 2000. 168 c.

9. Юник Д.Г. Виконавська надійність музикантів: зміст, структура i методика формування. Київ, 2009. 338 с.

\section{REFERENCES}

1. Abolin, L. M. (1990). Emotsionalnaya ustoychivost $\mathrm{v}$ napryazhennoy deyatelnosti, ee psikhologicheskiye mekhanizmy i puti povysheniya [Emotional stability in intense activity, its psychological mechanisms and ways to increase].

Extended abstract of Doctor's thesis. Moscov, 43 p.

[in Russian].

2. Bochkarev, L. L. (1974). Psikhologicheskiye aspekty formirovaniya gotovnosti muzykantovispolniteley $\mathrm{k}$ publichnomu vystupleniyu [Psychological aspects of the formation of the willingness of musicians to perform publicly]. Candidate's thesis. Moscov, 176 p. [in Russian].

3. Gotsdiner, A. L. (1991 - 1992). Podgotovka uchashchikhsya k kontsertnym vystupleniyam [Preparing students for concert performances]. Methodological notes on music education. Moscov, pp.182-192.[in Russian].

4. Kotova,L .M. (2016). Vplyv emotsiohennykh umov na nadiinist vykonannia muzychnykh tvoriv maibutnimy vchyteliamy mystetstva [The influence of the conditions to the hope of the performing the musical compositions of the future teachers]. "Youth and market". Monthly scientific-pedagogical journal. Drogobych,Vol.5(136), pp.93-98. [in Ukrainian].

5. Luchinina, O.A. \& Vinokurova, Ye.S. (2008). Prakticheskaya psikhologiya dlya muzykantov [Practical psychology for musicians]. 144p. [in Russian].

6. Rozhdestvenskaya, V.I. (1980). Individualnyye razlichiya rabotosposobnosti [Individual performance differences]. Moscov, 152 p. [in Russian].

7. Tsagarelli, Yu. A. (1989). Psikhologiya muzykalno-ispolnitelskoy deyatelnosti [The psychology of musical performance]. Doctor's thesis. Kazan, 425 p. [in Russian].

8. Shcherbatykh, Yu. V. (2000). Ekzamenatsionnyy stress (diagnostika, techeniye i korrektsiya) [Exam stress (diagnosis, course and correction)]. Voronezh, 168 p. [in Russian].

9. Yunyk, D.H. (2009). Vykonavska nadiinist muzykantiv: zmist, struktura $i$ metodyka formuvannia [Performing of musicians reliability: content, structure and method of formation]. Kyiv, 340 p. [in Ukrainian].

Стаття надійшла до редакції 10.05.2019

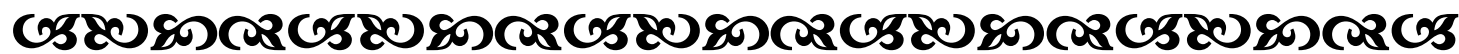

"Краще йти до мети зі швидкістю черепахи, ніжзі швидқістю світла придумувати виправдання, чому ти стоїи на місиі”.

$$
\begin{array}{r}
\text { Бодо Шебер } \\
\text { німецький письменник, лектор }
\end{array}
$$

“Внутрішня сила - ие здатність поважати чужу музику, але танщювати під власну мелодію і слухати свою гармонію".

Doк Yuлдpe

американський письменник

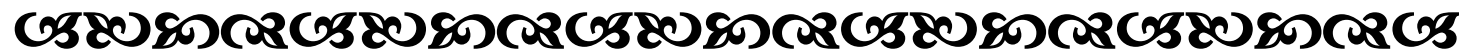

